\title{
(2) OPEN ACCESS \\ Extreme hypercalcaemia caused by immobilisation due to acute spinal cord injury
}

\author{
Jesse Marc Tettero, ${ }^{1}$ Elmer van Eeghen, ${ }^{2}$ Albertus Jozef Kooter ${ }^{2}$
}

${ }^{1}$ Hematology, Amsterdam UMC Location VUmc, Amsterdam, The Netherlands

Internal Medicine, Amsterdam UMC Location VUmc, Amsterdam, The Netherlands

Correspondence to Dr Albertus Jozef Kooter; JKooter@amsterdamumc.nl

Accepted 5 May 2021

Check for updates

(c) BMJ Publishing Group Limited 2021. Re-use permitted under CC BY-NC. No commercial re-use. See rights and permissions. Published by BMJ.

To cite: Tettero JM,

van Eeghen E, Kooter AJ. BMJ Case Rep 2021:14:e241386. doi:10.1136/bcr-2020241386

\section{SUMMARY}

Hypercalcaemia due to immobilisation is an uncommon diagnosis and requires extensive evaluation to rule out common causes of hypercalcaemia such as primary hyperparathyroidism and malignancy.

We report an unusual case of profound hypercalcaemia due to immobilisation in a young man due to acute spinal cord ischaemia, leading to paraplegia. Other causes of hypercalcaemia were ruled out and elevated bone turnover markers supported our hypothesis. Conventional treatment with intravenous fluids, bisphosphonates and diuretics was insufficient. Subcutaneous calcitonin lowered the plasma calcium acutely and was continued for 8 weeks. Subsequent normocalcaemia was sustained for 2 years.

\section{BACKGROUND}

The increase of plasma calcium due to immobilisation in hospitalised patients is often mild and negligible. In contrast, the hypercalcaemia may be severe when immobilisation is acute and pronounced, especially in young people with a high peak bone mass. We present a case of a young man who presents with severe hypercalcaemia after becoming completely immobilised following spinal cord injury (SCI). If the first-line treatment for hypercalcaemia is insufficient to substantially lower the plasma calcium, second-line treatments with calcitonin or denosumab can be considered.

\section{CASE PRESENTATION}

A 23-year-old man in good condition, with a medical history of thoracic endovascular aortic repair (TEVAR) for aorta injury due to trauma 2 years before, had an occlusion in the TEVAR leading to thoracic cord ischaemia, intestinal ischaemia and paraplegia. The patient was treated with a hemicolectomy with removal of $50 \mathrm{~cm}$ of ischaemic intestines combined with a high-output ileostomy and start of total parenteral nutrition. Postoperative blood test showed no abnormalities and the patient was discharged after 10 days to a rehabilitation centre. His plasma calcium was normal at discharge.

In the ensuing weeks, the patient suffered from increasing headache, nausea, thirst, slurred speech, vomiting and severe neuropathic pain in both legs. One month after paraplegia, the patient was resubmitted to the hospital.

\section{INVESTIGATIONS}

His initial blood tests are shown in table 1: abnormal results are in red. On admission, he had a pulse rate of 88 beats/min and a blood pressure of $142 / 87 \mathrm{~mm} \mathrm{Hg}$. His ECG showed shortening of the QT interval. Further diagnostics for a malignancy showed absence of $\mathrm{M}$-protein and free light chains, furthermore a positron emission tomography-CT scan showed no bone lesions.

\section{DIFFERENTIAL DIAGNOSIS}

Blood tests ruled out most causes of hypercalcaemia: primary hyperparathyroidism, granulomatous disease (normal $1.25(\mathrm{OH}) 2$-vitD) and tumour related. The patient had not consumed excessive amounts of calcium. Total parenteral nutrition is associated with hypercalcaemia, but only after administration for a longer period of time and resulting in only a modest increase in plasma calcium. ${ }^{1}$ We hypothesised that hypercalcaemia was due to bone resorption caused by sudden immobilisation, which was supported by elevated bone turnover markers procollagen type $1 \mathrm{~N}$-terminal propeptide (P1NP) and C-terminal telopeptide (CTx). Similar cases have been reported previously, including a case series, that described 10 patients with sudden immobilisation due to SCI; all of them with extreme hypercalcaemia, up to $4 \mathrm{mmol} / \mathrm{L}^{2}{ }^{2}$

\section{TREATMENT}

Treatment started with intravenous fluids (4 L in 24 hours), furosemide and pamidronic acid intravenously, but this only resulted in a modest decrease of plasma calcium to $4.2 \mathrm{mmol} / \mathrm{L}$ within 3 days. Although this time was too short to consider the effect of pamidronic acid as insufficient, we escalated treatment by adding calcitonin, based on a case series describing the successful treatment of severe hypercalcaemia with calcitonin. ${ }^{3}$

\section{OUTCOME AND FOLLOW-UP}

The effect of calcitonin was profound, with normalisation of plasma calcium within 48 hours after start of treatment. The patient received 100 IU calcitonin subcutaneous three times per day for 6 consecutive days. An overview of calcium levels and calcitonin administration in the first month after admission can be found in figure 1. During this month, we reduced the dose to 100 IU once a day and made multiple attempts to discontinue calcitonin, but hypercalcaemia recurred repeatedly. The fourth attempt, 1 month after start of treatment, was successful, after which normocalcaemia persisted for the following 2 years. The patient received calcitonin for a month, but no side-effects were 


\begin{tabular}{|c|c|c|}
\hline & Value & Reference \\
\hline Plasma calcium (mmol/L) & 4.28 & $2.2-2.6$ \\
\hline Albumin $(g / L)$ & 33 & $35-52$ \\
\hline Creatinine $(\mu \mathrm{mol} / \mathrm{L})$ & 92 & 64-104 \\
\hline Phosphate (mmol/L) & 1.04 & $0.7-1.4$ \\
\hline Magnesium (mmol/L) & 0.84 & $0.7-1.0$ \\
\hline Sodium (mmol/L) & 138 & $136-146$ \\
\hline Potassium (mmol/L) & 4 & $3.6-4.8$ \\
\hline PTH (pmol/L) & 0.6 & $<10$ \\
\hline 25-OH-vitamin-D (nmol/L) & 25 & $>50$ \\
\hline 1.25-vitamin-D (pmol/L) & 32 & 59-159 \\
\hline TSH (mU/L) & 2.3 & $0.3-4.5$ \\
\hline PTH-rp (pmol/L) & $<0.3$ & $0-0.6$ \\
\hline P1NP (ng/mL) & 461 & $<87$ \\
\hline CTx (ng/mL) & 1930 & $<584$ \\
\hline
\end{tabular}

Abnormal values are shown in red.

CTx, C-terminal telopeptide; P1NP, procollagen type $1 \mathrm{~N}$-terminal propeptide; PTH, parathyroid hormone; PTH-rp, parathyroid hormone-related protein; TSH, thyroidstimulating hormone.

noticed. After intensive rehabilitation for nearly 2 years, the patient was able to walk again. He recently finished a 10-kilometre run in his hometown.

\section{DISCUSSION}

The first association between immobilisation and hypercalcaemia dates back to $1941 .^{4}$ Immobilisation slightly increases plasma calcium concentration in many hospitalised patients, whereas acute and pronounced immobilisation can lead to extreme hypercalcaemia. ${ }^{25}$ Young adult men with a high peak bone mass are especially prone to develop extreme hypercalcaemia after sudden neurological injuries such as cervical levels of SCI. The diagnosis is made after ruling out more common causes of hypercalcaemia. Elevated bone turnover markers, such as P1NP and CTx, can support the diagnosis but should not be used to specify the severity of turnover.

The increased bone remodelling and release of calcium from the bones is not completely understood but seems to be multicausal. First, a complete and sudden loss of mechanical

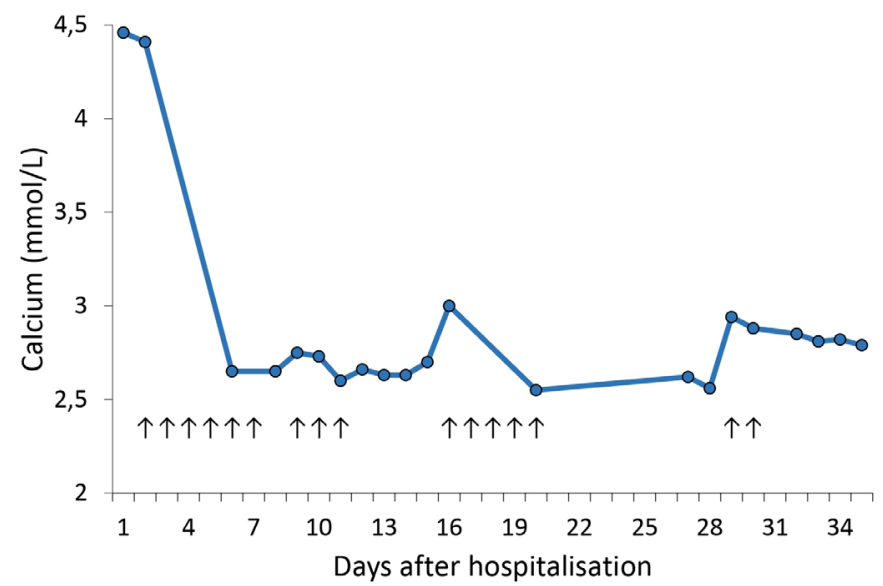

Figure 1 Relationship between calcium and calcitonin in the first month. Every arrow represents a day on which calcitonin was administered, $100 \mathrm{IU}$ three times per day during the first 6 days and 100 IU once daily in the ensuing days. forces (gravitational and muscular) on bones increases osteoclastic bone resorption (as seen in space travel). ${ }^{7}$ This is accompanied by excessive sclerostin production from osteocytes, which supresses the Wnt-Runx2 pathway causing reduced osteoblastic bone formation. ${ }^{8} 9$ Lastly, the denervation of the sympathetic neural fibres in the bone has a direct and indirect (via vascular dysregulation) impact on bone loss. ${ }^{1011}$ This could explain why excessive increase in plasma calcium is relatively often seen in patients with SCI, although the contribution of each mechanism to the total increase of bone remodelling is unknown. The higher turnover can be seen especially in the first months post-injury. ${ }^{10}$ In this case, pamidronic acid or stronger bisphosphonates still is the first-choice therapy, but the effect can take a few days or even longer. Therefore, the addition of calcitonin to intravenous fluids and loop diuretics can be indicated in severe cases. ${ }^{31213}$ The calcium-lowering effect of calcitonin is caused by a reduced efflux of calcium from the bone to the extracellular fluid by inhibiting osteoclasts and stimulating osteoblasts, inhibiting calcium absorption by the intestines and finally, by decreasing tubular reabsorption of calcium. ${ }^{14}$ The sudden fall of plasma calcium after starting calcitonin and the recurrence of hypercalcaemia after discontinuation support a substantial effect of calcitonin in lowering the plasma calcium. Long-term use of calcitonin should be avoided as it increases the risk of cancer according to the European Medicines Agency. ${ }^{15}$ Alternatively, denosumab can also be considered as additional treatment. There is a growing evidence of the effect of denosumab on immobilisationrelated hypercalcaemia. ${ }^{16}{ }^{17}$ However, this should come with major caution because of lack of specific long-term safety data in this off-label setting.

\section{Patient's perspective}

I remember little of my first weeks in the hospital. I had a lot of pain and felt very weak. My relatives particularly remember incoherent speech; I could talk for hours about flying dogs and imaginary creatures. They also remember the first dose of calcitonin and how I changed in the following three days. I received a lot of medication during this time and I cannot remember which one was the calcitonin or how it affected me. I'm still rehabilitating almost 1.5 year after the incident and making progress. The doctors in the hospital told me that I was probably never going to walk independently whereas I can now walk ten kilometres. My main problem is keeping balance because the sensitivity in my feet is still reduced, but I won't complain as my recovery has already exceeded all expectations.

\section{Learning points}

- Severe hypercalcaemia may be caused by sudden and profound immobilisation.

- This uncommon diagnosis can be induced by spinal cord injury in young vital patients.

- The addition of subcutaneous calcitonin to usual treatment of hypercalcaemia can be considered in severe life-threatening cases where acute drop of calcium is of paramount significance. 
Contributors JMT wrote the manuscript with input from all authors. EvE and AJK critically revised the manuscript.

Funding The authors have not declared a specific grant for this research from any funding agency in the public, commercial or not-for-profit sectors.

Competing interests None declared.

\section{Patient consent for publication Obtained.}

Provenance and peer review Not commissioned; externally peer reviewed.

Open access This is an open access article distributed in accordance with the Creative Commons Attribution Non Commercial (CC BY-NC 4.0) license, which permits others to distribute, remix, adapt, build upon this work non-commercially, and license their derivative works on different terms, provided the original work is properly cited and the use is non-commercial. See: http://creativecommons.org/ licenses/by-nc/4.0/.

\section{REFERENCES}

1 Shike M, Harrison JE, Sturtridge WC, et al. Metabolic bone disease in patients receiving long-term total parenteral nutrition. Ann Intern Med 1980;92:343-50.

2 Maynard FM. Immobilization hypercalcemia following spinal cord injury. Arch Phys Med Rehabil 1986;67:41-4.

3 Meythaler JM, Tuel SM, Cross LL. Successful treatment of immobilization hypercalcemia using calcitonin and etidronate. Arch Phys Med Rehabil 1993;74:316-9

4 Albright $\mathrm{F}$, BURNETT CH, Cope 0 , et al. Acute atrophy of bone (osteoporosis) simulating Hyperparathyroidism12. J Clin Endocrinol 1941;1:711-6.

5 Cano-Torres EA, González-Cantú A, Hinojosa-Garza G, et al. Immobilization induced hypercalcemia. Clin Cases Miner Bone Metab 2016;13:46-7.
6 Tori JA, Hill LL. Hypercalcemia in children with spinal cord injury. Arch Phys Med Rehabil 1978:59:443.

7 Orwoll ES, Adler RA, Amin S, et al. Skeletal health in long-duration astronauts: nature, assessment, and management recommendations from the NASA bone Summit. $J$ Bone Miner Res 2013;28:1243-55.

8 Lewiecki EM. Sclerostin: a novel target for intervention in the treatment of osteoporosis. Discov Med 2011;12:263-73.

9 Beggs LA, Ye F, Ghosh P, et al. Sclerostin inhibition prevents spinal cord injury-induced cancellous bone loss. J Bone Miner Res 2015:30:681-9.

10 Tan CO, Battaglino RA, Morse LR. Spinal cord injury and osteoporosis: causes, mechanisms, and rehabilitation strategies. Int J Phys Med Rehabil 2013;1:127.

11 Liang $H$, Zeng $Y$, Feng $Y$, et al. Selective $\beta 2$-adrenoreceptor signaling regulates osteoclastogenesis via modulating RANKL production and neuropeptides expression in osteocytic MLO-Y4 cells. J Cell Biochem 2019;120:7238-47.

12 Osterman J, Lin T, Durkin MW, et al. Hypercalcemia of immobilization in an adult patient with peripheral neuropathy. Am J Med Sci 1989;297:254-6.

13 Carey DE, Raisz LG. Calcitonin therapy in prolonged immobilization hypercalcemia. Arch Phys Med Rehabil 1985;66:640-4.

14 Naot D, Musson DS, Cornish J. The activity of peptides of the calcitonin family in bone Physiol Rev 2019;99:781-805.

15 European Medicines Agency. Assessment report for calcitonin containing medicinal products. Referral Assessment Report Procedure number: EMEA/H/A-31/1291, 2012

16 Malberti F. Treatment of immobilization-related hypercalcaemia with denosumab. Clin Kidney J 2012;5:491-5.

17 Uehara A, Yazawa M, Kawata A, et al. Denosumab for treatment of immobilizationrelated hypercalcemia in a patient with end-stage renal disease. CEN Case Rep 2017:6:111-4.

Copyright 2021 BMJ Publishing Group. All rights reserved. For permission to reuse any of this content visit

https://www.bmj.com/company/products-services/rights-and-licensing/permissions/

BMJ Case Report Fellows may re-use this article for personal use and teaching without any further permission.

Become a Fellow of BMJ Case Reports today and you can:

- Submit as many cases as you like

- Enjoy fast sympathetic peer review and rapid publication of accepted articles

- Access all the published articles

Re-use any of the published material for personal use and teaching without further permission

Customer Service

If you have any further queries about your subscription, please contact our customer services team on +44 (0) 2071111105 or via email at support@bmj.com.

Visit casereports.bmj.com for more articles like this and to become a Fellow 